補綴誌, J Jpn Prosthodont Soc, 40：276〜283, 1996.

原著論 文

\title{
オールセラミッククラウンの色調に支台歯の色調が及ぼす影響
}

斎藤 脩 中村 隆志 高島 史男 丸山 剛郎

\section{The Influence of the Color of the Abutment Tooth on the Color of All Ceramic Crowns}

\author{
Osamu Saitou, Takashi Nakamura, Fumio Takashima and Takao Maruyama
}

\begin{abstract}
All-ceramic crowns are the most esthetic, because they transmit light similarly to natural teeth.
However, because of the translucency of all-ceramic crowns, the color of the abutment tooth can affect the color of the final crowns.

The aim of this study was to investigate the influences of the color of the abutment tooth on all-ceramic crowns.

Ceramic disc specimens (In-Ceram, Hi-Ceram, Optec and G-cera II), metal disc abutment specimens (type IV gold and gold-silver-palladium alloy) and porcelain disc abutment specimens (A 1 and A 4) were used for the study. The color of ceramic specimens was measured with a small area colorimeter by translucent and reflectant methods and evaluated by the CIE L*a*b* color system.
\end{abstract}

The results were as follows:

1. All ceramic systems with an aluminous core have low translucency, so the color of the abutment tooth does not have to be considered.

2. All ceramic systems with masking porcelain have high reflectance, so the light reflectance have to be considered.

3. All ceramic systems with high translucency have to be considered due to the effect of the color of the abutment tooth.

Key words: all-ceramic crown, color, abutment tooth, colorimeter

\section{I. 緒言}

金属焼付ポーセレンクラウンは，セラミックスの審美性 と金属の強度を兼ね備えた歯冠補綴として臨床に広く普及 している。ところが，金属焼付ポーセレンクラウンは金属 を用いるために，不自然な白色感が現れたり，歯肉に着色 がおこるといった審美的な欠点を有していた ${ }^{1,2)}$.

近年このような金属焼付ポーセレンクラウンの問題点を 解決するために，高強度のアルミナスコアやキャスタブル セラミックスなどを用いた，新しいオールセラミッククラ

大阪大学歯学部歯科補経学第一講座（主任：丸山㴊郎教授）

Department of Fixed Prosthodontics, Osaka University Faculty of Dentistry (Chief : Prof. Takao Maruyama)

平成 7 年 10 月 1 日受付
ウン製作システムが開発された ${ }^{3 \sim 5)}$.オールセラミックク ラウンは，金属を使用せずに色調や光の透過性に優れたセ ラミックスだけでクラウンを作製するため，天然歯にきわ めて近い審美性の再現が可能であるといわれている。

しかしながら，どのオールセラミッククラウンにおいて も，金属焼付ポーセレンクラウンとは異なり，支台歯の色 調がある程度最終的な補綴物の色調に影響を及ほするとが 予想される. さらに，その影響はアルミナスコアの有無 など，オールセラミッククラウンを構成する材料によって 大きく異なることが考えられる。

そこで今回の研究では，使用する材料の異なる各種の オールセラミッククラウン製作システムを対象に，セラ ミック材料の透過光と反射光を測定して, 支台歯の色調が オールセラミッククラウンの色調に及ほすす影響を検討し た。 


\section{II. 方 法}

\section{1. 実験材料}

1）セラミック試料

今回の実験では, 高強度のアルミナスコアポーセレンを 用いるオールセラミッククラウンとしてインセラムおよび 八イセラム（いずれも Vita Zahnfabrik）を，加強因子の 含有により強度を向上させたオールセラミッククラウンと してオプテック (Jeneric/Pentron Inc.) およびジーセラ コスモテック II ((株)ジーシー)（以下ジーセラと略）を 用いた。インセラム，八イセラムではアルミナスコアポー セレンを, オプテックではデンチンポーセレンを, ジーセ ラではマスキングデンチンポーセレンをそれぞれ選択し， 各システムともにA 1, A 3, A 4 の色調を使用した。こ れらをメーカー指示通りに築盛, 焼成を行った後, ダイヤ モンドポイント, カーボランダムポイントにて調整を行っ た.さらにペーパーコーン，シリコーンポイントにて研磨 後, エメリーペーパー\#1500で最終研磨を行い, セルフ グレージングを行って試料とした. 試料は直径 $10 \mathrm{~mm}$ で, 厚さ $0.5,1.0 \mathrm{~mm}$ の 2 種類の円板状となるように作製し, 各 5 枚を用いた. 各試料の色調を表 1,2 に示す.

2) 背景試料

(1) 金合金試料

キャスティングゴールド M.C.タイプIV（(株)ジー シー）を厚さ $0.3 \mathrm{~mm}$, 直径 $10 \mathrm{~mm}$ の円板状に鋳造後, 通法通り研磨を行い試料とした (以下 $\mathrm{Au}$ 背景と略).

(2) 金銀パラジウム合金試料

キャストウェル M.C. 金 $12 \%$ （(株) ジーシー）を厚さ $0.3 \mathrm{~mm}$, 直径 $10 \mathrm{~mm}$ の円板状に鋳造後, 通法通り研磨を 行い試料とした(以下 $\mathrm{Pd}$ 背景と略).

表 1 The value of $\mathrm{L}^{*} \mathrm{a}{ }^{*} \mathrm{~b}^{*}$ of ceramic specimens in reflectant light (specimen thickness : 0.5 $\mathrm{mm}$ )

反射光におけるセラミック試料の $\mathrm{L}^{*} \mathrm{a}{ }^{*} \mathrm{~b}$ *值

\begin{tabular}{|c|c|c|c|c|}
\hline \multicolumn{2}{|c|}{ セラミック試料 } & \multirow{2}{*}{$\frac{L^{*}}{77.49}$} & \multirow{2}{*}{$\frac{a^{*}}{0.04}$} & \multirow{2}{*}{$\frac{b^{*}}{14.15}$} \\
\hline インセラム & A 1 & & & \\
\hline & A 3 & 74.62 & 1.58 & 15.85 \\
\hline & A 4 & 65.91 & 2.63 & 17.73 \\
\hline \multirow[t]{3}{*}{ ハイセラム } & A 1 & 87.95 & -0.60 & 12.68 \\
\hline & A 3 & 81.83 & 0.99 & 15.91 \\
\hline & A 4 & 77.33 & 2.93 & 19.80 \\
\hline \multirow[t]{3}{*}{ ジーセラ } & A 1 & 87.62 & -0.09 & 8.63 \\
\hline & A 3 & 82.07 & -0.09 & 10.62 \\
\hline & A 4 & 70.34 & 0.71 & 13.94 \\
\hline \multirow[t]{3}{*}{ オプテック } & A 1 & 69.87 & -1.90 & 8.63 \\
\hline & A 3 & 62.82 & -0.64 & 14.56 \\
\hline & A 4 & 58.32 & 0.56 & 16.96 \\
\hline
\end{tabular}

試料厚さ : $0.5 \mathrm{~mm}$, 背景：標準白色板

\section{(3) ポーセレン試料}

金属焼付ポーセレンクラウン用 VMK 68 ポーセレン (Vita Zahnfabrik) の A 1, A 4 色の各オペークとデンチ ンポーセレンを用いてポーセレン試料を作製した。オペー クポーセレンはメーカー指示通りに築盛, 焼成後, 調整し て厚さ $1.0 \mathrm{~mm}$, 直径 $10 \mathrm{~mm}$ の円板状とした。この上に 同じ色調のデンチンポーセレンを築盛，焼成した。焼成後 ペーパーコーン, シリコーンポイントで直径 $6.0 \mathrm{~mm}$, 厚 さ $2.0 \mathrm{~mm}$ の円板状に調整, 研磨してセルフグレージング を行った(以下それぞれ A 1 背景, A 4 背景と略).

各背景試料の色調を表 3 に示す.

\section{2. 実験方法}

1）測色装置および表色法

透過光の測色は MMP- $\Sigma 80$ Color Measuring System, 反射光の測色は OFC- $\Sigma 80$ Color Measuring System（い ずれも日本電色工業(株)）を用いて行った。これらの装置 は刺激值直読方式で, 3 刺激值により任意刺激值を量的に 表す方式である，表色には $\mathrm{L}^{*} \mathrm{a}^{*} \mathrm{~b}^{*}$ 表色法を用いた，透過 光については $L^{*}$ 值を, 反射光については $L^{*}$ 値, $a^{*}$ 値, b*值をそれぞれ検討した。

背景を変化させた際の試料の色調の相違は, 色差を算出

表 2 The value of $L^{*}{ }^{*}{ }^{*}{ }^{*}$ of ceramic specimens in reflectant light (specimen thickness : 1.0 $\mathrm{mm}$ )

反射光におけるセラミック試料の $\mathrm{L}^{*} \mathrm{a} \mathrm{a}^{*} \mathrm{~b}$ 值

\begin{tabular}{cc|rrr}
\hline \hline セラミック試料 & \multicolumn{1}{c}{$\mathrm{L}^{*}$} & \multicolumn{1}{c}{$\mathrm{a}^{*}$} & \multicolumn{1}{c}{$\mathrm{b}^{*}$} \\
\hline インセラム & A 1 & 76.29 & 0.02 & 13.12 \\
& A 3 & 73.26 & 1.34 & 14.85 \\
& A 4 & 65.51 & 2.38 & 17.27 \\
ハイセラム & A 1 & 87.90 & -0.60 & 11.66 \\
& A 3 & 80.48 & 0.86 & 14.31 \\
& A 4 & 76.63 & 2.59 & 19.58 \\
ジーセラ & A 1 & 86.69 & -0.29 & 7.43 \\
& A 3 & 81.37 & -0.11 & 9.26 \\
& A 4 & 69.74 & 0.21 & 13.14 \\
オプテック & A 1 & 66.17 & -1.20 & 8.15 \\
& A 3 & 60.88 & -0.44 & 13.50 \\
& A 4 & 57.66 & 0.46 & 16.29 \\
\hline
\end{tabular}

試料厚さ: $1.0 \mathrm{~mm}$, 背景: 標準白色板

表 3 The value of $L^{*} a^{*} b^{*}$ of abutment specimens in reflectant light 反射光に扔ける背景試料の $L^{*} a^{*} b^{*}$ 值

\begin{tabular}{|c|c|c|c|c|}
\hline 背 & 景 試 料 & $\mathrm{L}^{*}$ & $a^{*}$ & $\mathrm{~b}^{*}$ \\
\hline \multirow{2}{*}{ 金属 } & 金合金 & 56.73 & 3.13 & 17.19 \\
\hline & 金銀パラジウム合金 & 54.19 & 1.86 & 9.66 \\
\hline \multirow{2}{*}{ ポーセレン } & A 1 & 60.31 & -0.39 & 5.77 \\
\hline & A 4 & 55.21 & 0.54 & 13.64 \\
\hline
\end{tabular}

試料厚さ 金属: $0.3 \mathrm{~mm}$, ポーセレン: $2.0 \mathrm{~mm}$ 
して判定した. $L^{*} a^{*} b^{*}$ 表色法における色差 $(\Delta E)$ は次の 式で求めだ).

$$
\Delta \mathrm{E}=\sqrt{\left(\Delta \mathrm{L}^{*}\right)^{2}+\left(\Delta \mathrm{a}^{*}\right)^{2}+\left(\overline{\left.\Delta \mathrm{b}^{*}\right)^{2}}\right.}
$$

\section{2) 測色操作}

透過光の測色は, 標準光源 $\mathrm{D}_{65}$ のもとで装置の指示通り に行った.

反射光の測色は，臨床で支台歯の状態を測定して，先の 3 種類の背景試料の上にセラミック試料を重ねあわせ, 装 置の受光部がセラミック試料と密着する状態で行った。

\section{III. 結 果}

\section{1. 透過光の $\mathbf{L}^{*}$ 値}

透過光の $L^{*}$ 值は, どのシステムにおいても A 1 が最も
高く, 以下A 3, A 4 の順に低くなった.

4 種類のシステムを比較すると, 試料の厚さが $0.5 \mathrm{~mm}$ の場合, ハイセラム, インセラムでは $\mathrm{L}^{*}$ 值が小さく, 以 下ジーセラ, オプテックの順に $\mathrm{L}^{*}$ 值が大きくなってい た. 特にオプテックでは他の 3 システムよりも L*值がは るかに大きな值を示した。

この傾向は試料の厚さが $1.0 \mathrm{~mm}$ の場合においても同様 であった（図 1 ).

\section{2. 反射光の $L^{*}$ 值, $a^{*}$ 值, $b^{*}$ 值}

試料の厚さが $0.5 \mathrm{~mm}$ の場合は, $\mathrm{L}^{*}$ 值はどのシステム においても，試料の色調が A 1 の時に最も大きな值を示 し, 以下A $3, \mathrm{~A} 4$ の順に值が小さくなった（図 2 ). $\mathrm{a}^{*}$ 值, b*值は逆にどのシステムにおいても，A1の時に $\mathrm{a}^{*}$
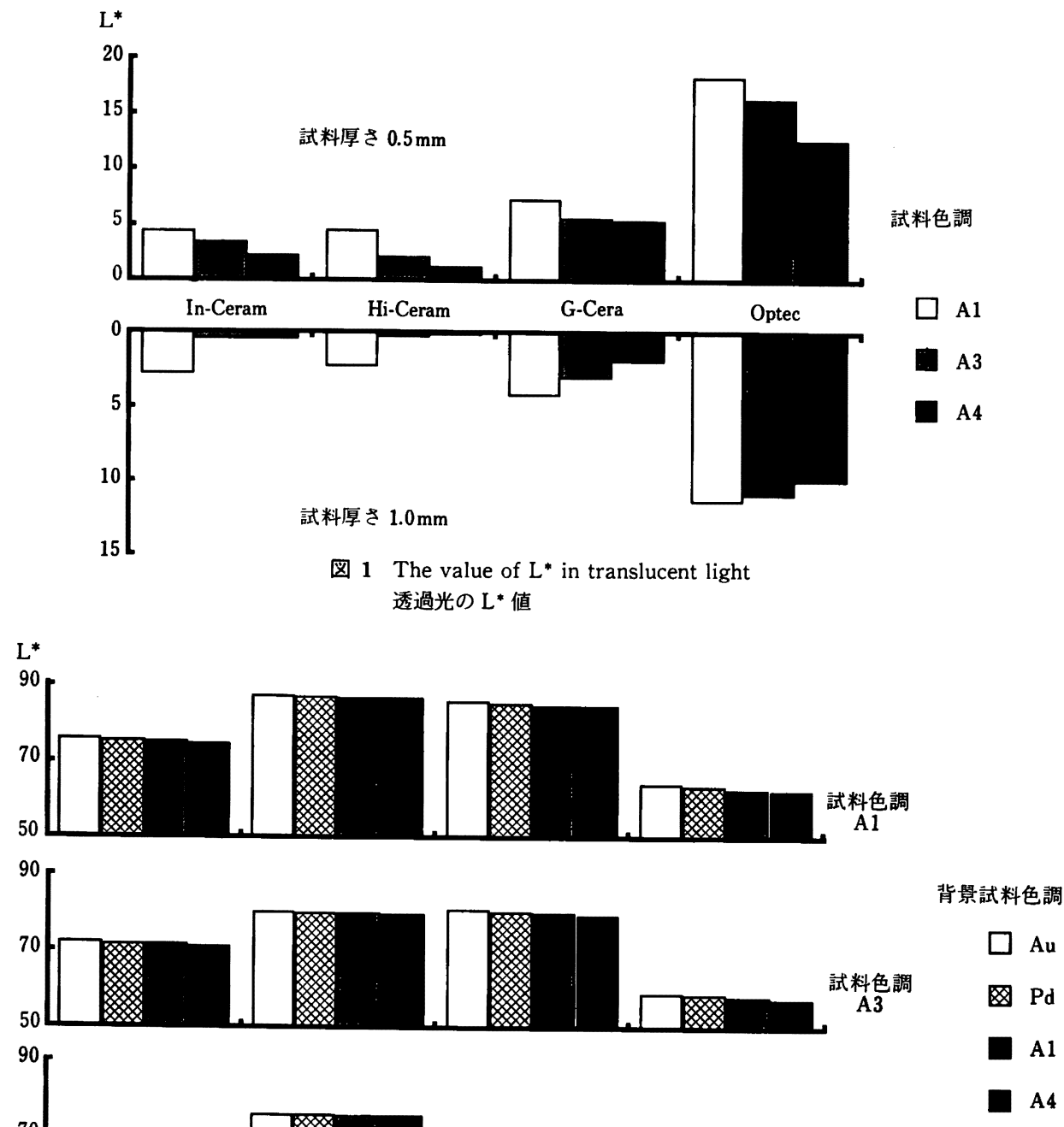

图 2 The value of $L^{*}$ in reflectant light (specimen thickness : $0.5 \mathrm{~mm}$ ) 反射光の $L^{*}$ 值 (試料厚さ $0.5 \mathrm{~mm}$ ) 


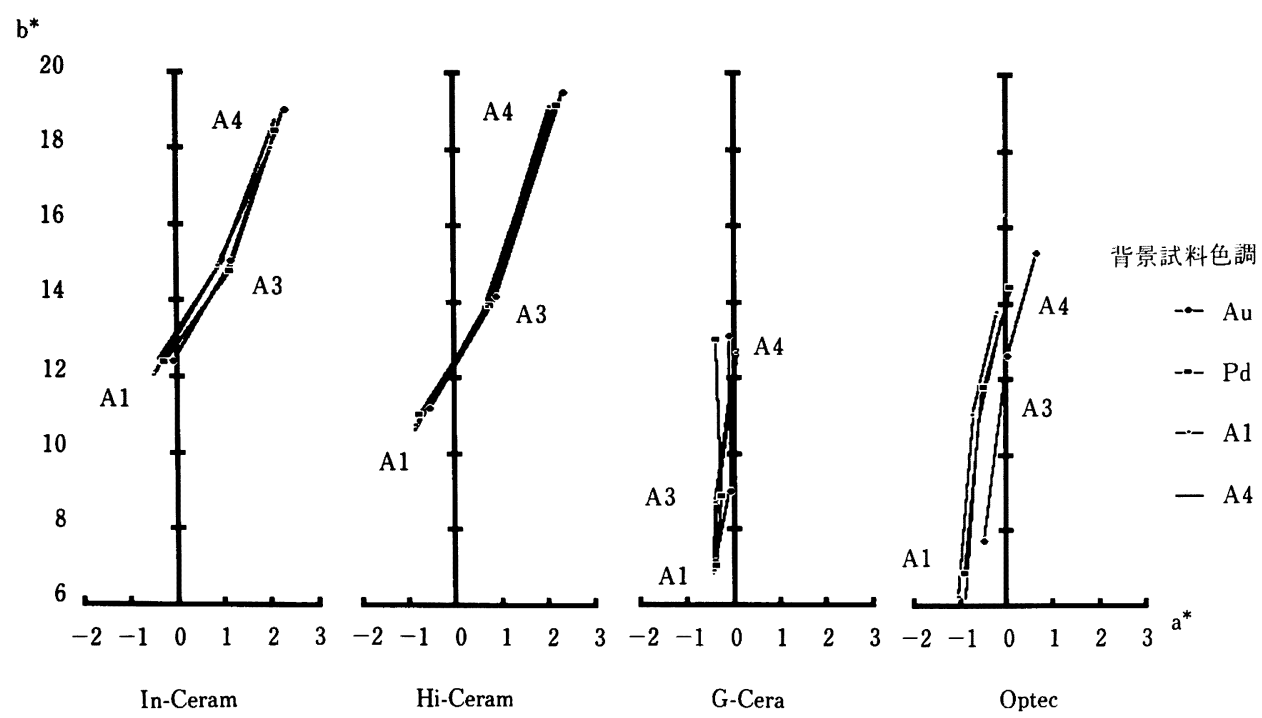

図 3 The value of $\mathrm{a}^{*}$ and $\mathrm{b}^{*}$ in reflectant light (specimen thickness $: 0.5 \mathrm{~mm}$ ) 反射光の $\mathrm{a}^{*} \mathrm{~b}^{*}$ 值（試料厚さ $0.5 \mathrm{~mm}$ )

值， $\mathrm{b}^{*}$ 値ともに最も小さく，以下 A 3, A 4 と順に大きく なっていた (図 3 ).

各システムを比較した場合, 厚さが $0.5 \mathrm{~mm}$ の場合は, 八イセラム, ジーセラが大きな $\mathrm{L}^{*}$ 值を示し, 以下インセ ラム,オプテックの順になっていた (図 2 ). $\mathrm{a}^{*}$ 值, $\mathrm{b}^{*}$ 值に関しては, インセラムと八イセラムの 2 つのシステム の場合, $a^{*}$ 值, $b^{*}$ 值ともに大きな相違がなく近い彩度を 示した. またこれら 2 つのシステムは A 1 から A 4 へと 試料の色調が移行するにつれて $\mathrm{a}^{*}$ 值, $\mathrm{b}^{*}$ 值ともに増加す る傾向を示した。ジーセラやインセラムやハイセラムより も $\mathrm{a}^{*}$ 值, $\mathrm{b}^{*}$ 值がともに小さな值を示し, 試料の色調が A 1 から A 4 へと移行した場合についても， $\mathrm{a}^{*}$ 值の増加 はほとんど認められなかった。オプテックではインセラ ム, 八イセラムよりも $a^{*}$ 值, $b^{*}$ 值がともに小さな值を示 した。またオプテックでは, ジーセラよりも a*值は小さ く, $\mathrm{b}^{*}$ 值は大きくなっていた（図 3 ).

試料の厚さが $0.5 \mathrm{~mm}$ の場合, インセラム, ハイセラム およびジーセラでは背景の色調の相違によるセラミック試 料の色調への明らかな影響は認められなかった。しかし， オプテックの場合は背景の色調の相違, 特に $\mathrm{Au}$ 背景と他 の背景を比較した場合， $\mathrm{a}^{*}$ 值， $\mathrm{b}^{*}$ 值が明らかに異なり， セラミック試料の色調への影響を認めた（図 3 ).

試料の厚さが $1.0 \mathrm{~mm}$ の場合でも, $\mathrm{L}^{*}$ 值, $\mathrm{a}^{*}$ 值, $\mathrm{b}^{*}$ 值の結果は, 試料の厚さが $0.5 \mathrm{~mm}$ の場合とほほ同様の傾 向を示していた（図 4,5).

\section{3. 色差}

インセラムでは試料の厚さが $0.5 \mathrm{~mm}$ の場合, 試料色調 $\mathrm{A} 1$ の時に $\mathrm{Au}$ 背景一A 4 背景および $\mathrm{Pd}$ 背景一 A 4 背景 の間で色差を認めた。試料の色調が A 3 および A 4 試料
の場合，さらに試料の厚さが $1.0 \mathrm{~mm}$ の場合にはすべての 色調において, 背景の相違により試料の色調に色差を認め たものはなかった。

八イセラムでは試料の厚さが $0.5 \mathrm{~mm}$ の場合, 試料色調 $\mathrm{A} 1$ の時に Au 背景一 A 4 背景の間で色差を認めた。試料 の色調が A 3 およびA 4 試料の場合, さらに試料の厚さ が $1.0 \mathrm{~mm}$ の場合にはすべての色調において, 背景の相違 により色差を認めたものはなかった。

ジーセラでは試料の厚さが $0.5 \mathrm{~mm}$ の場合, 試料色調 $\mathrm{A} 1$ の時に $\mathrm{Au}$ 背景一 $\mathrm{A} 4$ 背景および $\mathrm{Pd}$ 背景一 $\mathrm{A} 4$ 背景 の間で色差を認めた。ジーセラの場合も，インセラム，八 イセラムと同様に試料の色調が A 3 および A 4 試料の場 合, さらに試料の厚さが $1.0 \mathrm{~mm}$ の場合にはすべての色調 で, 背景の相違により試料の色調に色差を認めたものはな かった.

オプテックでは背景の相違により試料の色調に色差を認 めたものが多く, 試料の厚さが $0.5 \mathrm{~mm}$ のものでは試料色 調 A 1 のすべての場合, さらに Pd 背景一 A 1 背景, A 1 背景一A 4 背景を除いた試料色調 A 3, A 4 の場合に色差 を認めた，試料の厚さが $1.0 \mathrm{~mm}$ の場合でも同様に，背景 の相違により試料の色調に色差を認めたものが多くみられ た（表 4,5).

\section{IV. 考 察}

\section{1. 実験方法について}

1) セラミック試料について

現在臨床で用いられるオールセラミッククラウンは, 強 度を向上させるために，アルミナスコアポーセレンを用い ているもの ${ }^{4,8,9)}$ と, 加強因子を含有しているもの ${ }^{3,5)}$ とに大 
$L^{*}$
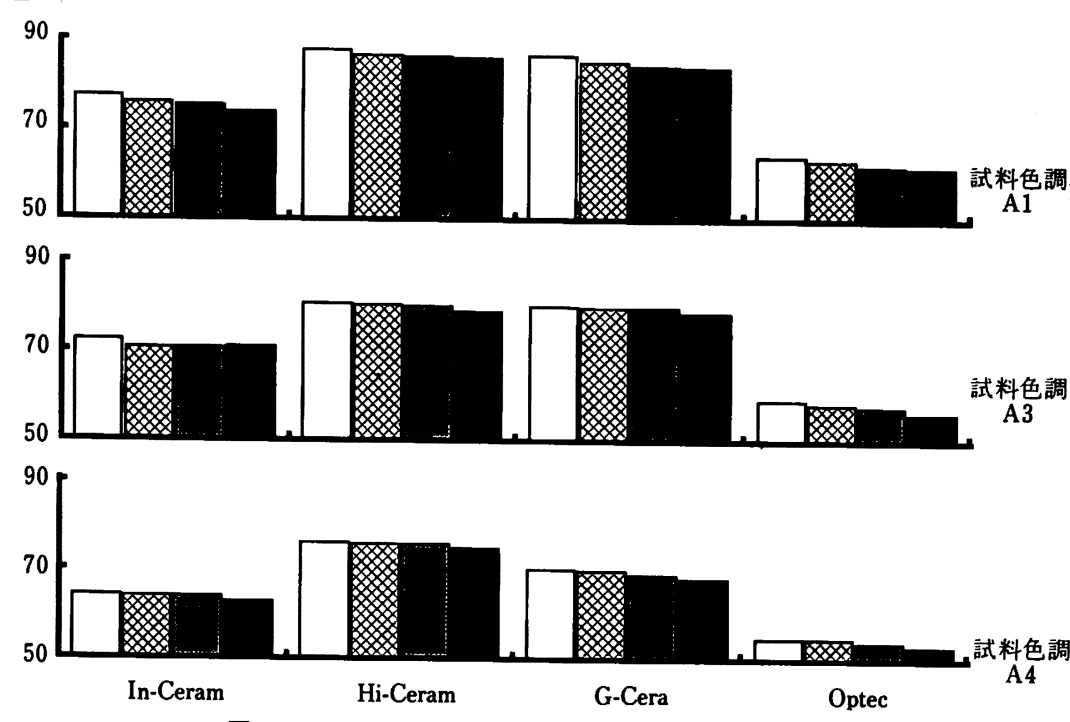

背景試料色調

图 4 The value of $L^{*}$ in reflectant light (specimen thickness : $1.0 \mathrm{~mm}$ ) 反射光の $\mathrm{L}^{*}$ 值 (試料厚さ $1.0 \mathrm{~mm}$ )
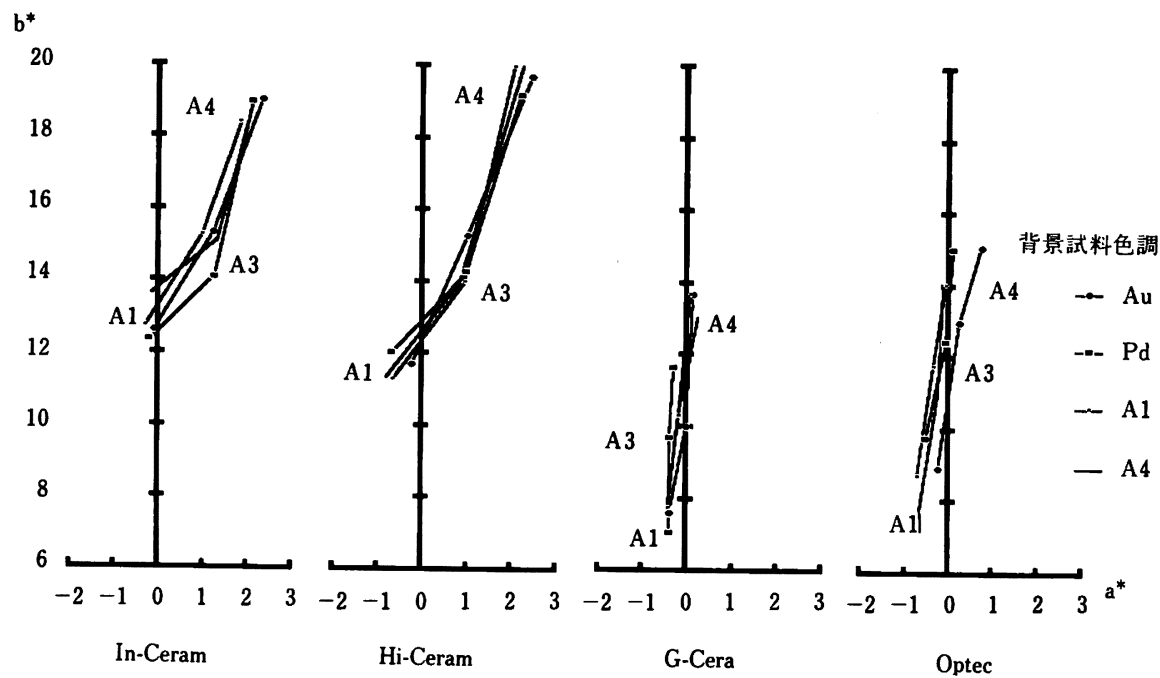

图 5 The value of $a^{*}$ and $b^{*}$ in reflectant light (specimen thickness : $1.0 \mathrm{~mm}$ ) 反射光の $\mathrm{a} * \mathrm{~b} *$ 值（試料厚さ $1.0 \mathrm{~mm}$ )

表 4 The color difference of ceramic specimens at the different abutment (specimen thickness : $0.5 \mathrm{~mm}$ )

支台歯の相違による試料の色差（試料厚さ：0.5 mm）

\begin{tabular}{l|cccccc}
\hline \hline & $\mathrm{Au}-\mathrm{PD}$ & $\mathrm{Au}-\mathrm{A} 1$ & $\mathrm{Au}-\mathrm{A} 4$ & $\mathrm{Pd}-\mathrm{Al}$ & $\mathrm{Pd}-\mathrm{A} 4$ & $\mathrm{~A} 1-\mathrm{A} 4$ \\
\hline インセラム & - & - & + & - & + & - \\
ハイセラム & - & - & + & - & - & - \\
ジーセラ & - & - & + & - & + & - \\
オプテック & $H$ & $H$ & + & + & $H$ & + \\
\hline
\end{tabular}

一：色差なし, + : 試料色調 A 1 で色差あり, $\#$ : 試料色調 A 1, A 3 およびA 4 で色差あり

別される.アルミナスコアポーセレンを用いるものは最初 に高強度のアルミナスコアを作製し，この上に歯冠色ポー セレンを築盛, 焼成してクラウンを作製する.これに対し
表 5 The color difference of ceramic specimens at the different abutment (specimen thickness : $1.0 \mathrm{~mm}$ ) 支台歯の相違による試料の色差 (試料厚さ $: 1.0 \mathrm{~mm}$ )

\begin{tabular}{l|cccccc}
\hline \hline & $\mathrm{Au}-\mathrm{PD}$ & $\mathrm{Au}-\mathrm{A} 1$ & $\mathrm{Au}-\mathrm{A} 4$ & $\mathrm{Pd}-\mathrm{A} 1$ & $\mathrm{Pd}-\mathrm{A} 4$ & $\mathrm{Al}-\mathrm{A4}$ \\
\hline インセラム & - & - & - & - & - & - \\
ハイセラム & - & - & - & - & - & - \\
ジーセラ & - & - & - & - & - & - \\
オプテック & $H$ & $H$ & + & + & $H$ & - \\
\hline
\end{tabular}

一：色差なし, +：試料色調 A 1 で色差あり, \#：試料色調 A 1, A 3 およびA 4 で色差あり

て加強因子を含有しているものは，歯冠色ポーセレンその ものにアルミナ $\left(\mathrm{Al}_{2} \mathrm{O}_{3}\right)$, マイカ (Tetrasilicic Fluormica) やリューサイト (Leucite $: \mathrm{K}_{2} \mathrm{O} \cdot \mathrm{Al}_{2} \mathrm{O}_{3} \cdot 4 \mathrm{SiO}_{2}$ ) 
といった加強因子を含有することでクラウン全体の強度を 向上させている。 また作製方法も耐火模型上でポーセレン を築盛, 焼成するもの, ロストワックス法を用いて作製し た鋳型に，セラミックスのインゴットを鋳造あるいは加熱 加圧により成型するものなど多様である.

これらのオールセラミッククラウン製作システムのなか で, 今回はアルミナスコアポーセレンを用いるシステム 2 種類と, 加強因子を含有したシステム 2 種類を対象として 実験を行った.今回用いた 4 種類はいずれも耐火模型を用 いてクラウンを作製するシステムである.

実験で用いた 4 種類のシステムのうち，インセラムと八 イセラムはアルミナスコアポーセレンの上に歯冠色ポーセ レンを築盛して色調再現を行っている. 他のアルミナスコ アを使用しない 2 種類のうち, ジーセラでは, ある程度遮 蔽性を持つマスキングポーセレンの上にデンチン, エナメ ルなどの歯冠色ポーセレンを築盛するが, オプテックでは このようなマスキングポーセレンは含まれていない.

実験は, 各システムにおいてクラウンの最内層に使用さ れるポーセレンを対象として行った。これは, いずれのシ ステムも, これらのポーセレンの透過性が最も低く, クラ ウン全体の色調透過性に大きな影響を与えると考えられる ことに加え, 彩度が最も高いため色調の特徵が現れやすい ことを考慮したことによる(10).

セラミック試料の色調は, 現在臨床で広く使用され, ま た天然歯のシェードテイキングに適した層構成を持っ LUMIN VACUUM シェードガイド (Vita Zahnfabrik) をもとにして, 歯冠色として最も発現頻度の高いA（黄褐 色）系統の色調を基準とした ${ }^{11}$.

アルミナスコアポーセレンを用いる場合, 強度を確保す るためにアルミナスコアは最低でも $0.5 \mathrm{~mm}$ の厚さが必要 であるといわれている12).このため実験ではセラミック試 料の厚さを $0.5 \mathrm{~mm}$ とし, アルミナスコアを使用しないも のについても比較のため厚さを同じ $0.5 \mathrm{~mm}$ とした。 た, セラミック試料の厚さが色調に及ぼす影響を検討する ため, オールセラミッククラウンを作製する場合に最低必 要であるといわれている厚さ $1.0 \mathrm{~mm}$ の場合についても実 験を行った.

2) 測色について

実験では, 透過光と反射光による測色を行った. 物体表 面の色調を客観的に評価する方法としては反射光の測色を 行うのが一般的である. しかし, 歯やセラミックスは半透 過性物質であり,これらの測色は完全な透過性物質や, 不 透過性物質の測色と比べると透過, 吸収, 散乱, 反射など が複雑に影響することが考えられる．そのため背景を変え た場合の反射光の測色に加えて, 透過光の測色を行い, 吸 収, 反射などを考慮して, セラミック試料の色調を検討し た.

色差は物体間の色調の相違を判定する場合に用いるが,
その基準值は測色法，用途などにより異なる.一般に色差 を知覚できる值は $2.5 〜 4$ 程度といわれているが, 特定の 業種に従事する専門家にとって, 色調の相違を許容できな い範囲は色差 1.2 であるといわれている(13). そこで今回 は, 色差 1.2 以上のものを色差あり, すなわち異なる色調 であるとした。

\section{2. 結果について}

1）透過光について

セラミックスの透過光に影響を与える要因としては気 孔, 粒度およびガラス質原料中に含まれる結晶の違いなど があげられる ${ }^{14,15)}$.

気孔は製作時に埋入されるため, 製作法が気孔の発生頻 度, 大きさなどに影響を及ぼす可能性がある. 今回使用し たシステムはインセラム以外はほぼ同一の方法で築盛, 焼 成して製作しているので, システムが異なっても, 気孔が 色調に及ほす影響に大きな相違はないものと思われる。し かしインセラムはアルミナスコアの焼成後ガラス材の浸潤 を行うという他のシステムとは異なった製作法を用いてい る. そのため, インセラムでは気孔がある程度ガラス材で 満たされることから, 気孔の影響が少なくなることが予想 される。

セラミックスは, 粒度が小さいものほど多数の細かい気 孔が分散し, それに伴い粒界も多くなる.この結果, 光の 散乱, 反射が起こりやすくなるため, 粒度が小さいほど透 過性が低下する. 今回の実験で透過光の L*值が小さな值 を示したインセラムやハイセラムはアルミナを含有してお り, このアルミナの粒度が小さいために透過光の $\mathrm{L}^{*}$ 值が 小さくなっていたものと考えられる.さらにジーセラで も, アルミナが含有されているため, これらと同様に $\mathrm{L}^{*}$ 值が小さくなっていたと考えられる.これに対してオプ テックでは加強因子として含有されるリューサイトの粒度 が大きいため, 他のシステムよりも透過光の $\mathrm{L}^{*}$ 值が大き くなったものと推察される.

一般に歯科用セラミックスではセラミックスの結晶相よ りもガラス相が多く，約 $50 \sim 60 \%$ がガラス相である.こ のガラス相での光の透過は通常の場合均一であるため, 結 晶の違いがセラミックスの透過性に大きく影響を及ほす. 今回のシステムのなかでアルミナスコアを使用するインセ ラム，ハイセラムおよびアルミナを含有するジーセラでは 透過光の $L^{*}$ 值が小さくなっていた.これはガラス相の屈 折率が 1.48 1.51 程度であるのに対して ${ }^{(4)}$, アルミナの 屈折率が 1.78 と極端に高く ${ }^{14)}$, このためガラスとアルミ ナの界面において光の散乱が生じやすくなり，この結果 L*值が小さくなったものと思われる.

アルミナスコアを用いるインセラムとハイセラムの $2 つ$ のシステムを比較した場合, インセラムで約 $85 \%$, 八イ セラムで約 $60 \%$ と，インセラムの方がアルミナの含有率 
が高いにもかかわらず，インセラムの透過光の $\mathrm{L}^{*}$ 值が大 きくなっていた。これはインセラムでは, 先に述べた気孔 の影響が少ないこと, アルミナの含有率が非常に高く, ア ルミナ単体に近づくためガラス相との界面が少なくなり, 屈折, 散乱などが少なくなることなどに加え, 特殊なガラ ス材を浸潤させることで試料内での屈折, 散乱が起こりに くくなるためであると考えられる.

これに対し，マイカやリューサイトなどの加強因子はセ ラミックスの結晶相として光の散乱，反射を起こすが，ア ルミナと比べ光の屈折率がガラスに近く, 光透過性が減少 しにくい.オプテックは加強因子としてリューサイトを含 んでいるが,このリューサイトが持つ光の屈折率は約 1.51 とガラスの届折率とほとんど同じ ${ }^{14}$ であるため光の 散乱, 反射が少なく, 透過性を減少する度合いが低くな り, 結果として他の材料よりも透過光の $\mathrm{L}^{*}$ 值が大きく なったものと考えられる.

2) 反射光について

アルミナスコアを用いるインセラムとハイセラムを比較 した場合，透過光の $\mathrm{L}^{*}$ 值は近似しているが，反射光の L*值は八イセラムが大きくなっていた。これは八イセラ ムでは試料表面での光の反射が大きいのに対し，インセラ ムでは試料内での光の吸収, 散乱, 反射が大きいためであ ると考えられる.

ジーセラでは透過光の $\mathrm{L}^{*}$ 值がインセラム, ハイセラム よりも大きくなっていた. また，反射光の $L^{*}$ 値はインセ ラムよりも大きく，ハイセラムに近似していた。 ジーセラ と八イセラムを比較した場合に，八イセラムが試料の色調 がA 1 から A 4 へと移行した場合でも $\mathrm{L}^{*}$ 值の隇少が少な いのに対し，ジーセラでは試料色調がA 1 からA 4 へと した場合に $\mathrm{L}^{*}$ 值の減少が顕著であった。この結果から， 八イセラムでは試料表面での反射が一定であるのに対し， ジーセラでは試料色調の移行に伴い, 試料内面への吸収が 大きくなっているものと考えられる.

インセラム, ハイセラムそしてオプテックのように $\mathrm{a}^{*}$ 值, $b^{*}$ 值が大きいもの, すなわち彩度の高いものほど, 試料内での光の吸収, 散乱が大きくなることが予想され る.インセラムとオプテックを比較した場合, インセラム の彩度がオプテックょりも高いため, 光の吸収が大きくな り, このこともインセラムの透過光がオプテックの透過光 よりも小さくなっている原因の 1 つであると考えられる.

背景の色調の影響においても同様に，セラミック試料を 透過して背景試料表面に達した光は，A 1 背景のように背 景試料のシェード番号が小さいものでは背景試料表面での 反射が多くなっていたことが推察される。これに対して A 4 背景のように背景試料のシェード番号が大きいもので は背景試料内への吸収, 散乱が多くなり, セラミック試料 に到達する反射光が少なくなっていたと考えられる.

また反射光の $L^{*}$ 值が大きい八イセラムやジーセラにお
いてもセラミック試料のシェード番号の増加, すなわち彩 度の増加に伴い反射光の割合が減少し, 試料内での吸収の 割合が増加したものと考えられる.

金合金, 金銀パラジウム合金などの金属の背景試料は, ポーセレンの背景試料と異なり, 背景試料内への光の透 過，吸収が少なく，背景の色調の相違がセラミック試料の 色調に影響を及ほしやすい.このため金属背景試料の色調 は,オプテックのように透過光の $\mathrm{L}^{*}$ 值が大きいセラミッ ク試料の色調に影響を及ほしやすかったものと考えられ $3^{6,16)}$

今回の実験のように，同じ耐火模型を用いる 4 種のシス テムであっても，クラウンの構造あるいは使用する材料の 相違により，クラウンの色調や支台歯の色調の影響が大き く異なることが示唆された. 最近では, マグネシアやジル コニアを用いてクラウンの強度を向上させるシステムも研 究されており ${ }^{17)}$,オールセラミッククラウンの種類はます ます増える傾向にある，そこで，天然歯に近い色調と光の 透過性を再現できるというオールセラミッククラウンの特 徵をいかすためには，それぞれのシステムが持つ色調の特 徵をよく理解した上で処置を行うことが不可欠であろう.

\section{V. 結 論}

オールセラミッククラウンの色調に支台歯の相違が及ほ す影響を調べるために，セラミック試料を作製し，その透 過光の測定を行い, さらに背景試料上にセラミック試料を 重ねた場合の反射光を測色した結果, 以下のことが明らか となった。

1. アルミナスコアを用いてオールセラミッククラウン を作製するシステムでは，アルミナスコアの光の透過が小 さいため, 背景となる支台歯の色調の影響を考慮する必要 がないことが明らかとなった。

2. マスキングポーセレンを用いるシステムでは, 反射 光を考慮して色調の回復を行うことが必要であることがわ かった.

3. アルミナスコアやマスキングポーセレンを用いない システムでは, 光の透過が大きいため, 背景となる支台歯 の色調の影響を考慮する必要があることが明らかになっ た.

以上のことから，オールセラミッククラウンでは支台歯 の色調の影響に相違があることを考虑して, 適切な材料を 選択し材料の特徵をいかして, 色調の回復を図る必要があ ることが示唆された。

\section{文 献}

1）宮内修平. 歯科における色彩学. 日歯医師会誌 $40: 4-13,1987$.

2）尾島裕夫．歯肉に対する金属焼付ポーセレン冠の影響に関する 
実験的研究. 補緅誌 $22: 231-256,1978$.

3) Adair PJ, Grossman DG. The castable ceramic crown. Int J Periodont Res Dent 4:32-45, 1984.

4) Claus H. Das Hi-Ceram-Verfahren Metall-freie Kronen auf einem Keramikgerust. Dent Labor (Munch) $35: 479-482$, 1987.

5) Dong JK, Luthy H, Wohlwend A et al. Heat-pressed ceramics : Technology and strength. Int J Prosthodont 5 : 9-16, 1992.

6）斎藤 脩, 中村隆志, 丸山剛郎. 加熱加圧成型により作製する オールセラミッククラウンーIPS エンプレスーの色調に関する 研究. 補緅誌 39 ：153-158, 1995.

7）日本色彩学会編. 新編色彩科学ハンドブック 135-143, 東京： 東京大学出版会, 1980.

8) Ironside JG. Light transmission of a ceramic core material used in fixed prosthodontics. Quintessence Dent Technol 4 : 103-106, 1993.

9) 田中孝一, 中村隆志, 丸山剛郎. ブリッジに応用可能な新しい ポーセレンシステムIn-Ceramの臨床. QE 12:1459-1466,
1993.

10）吉田 皓. 陶材の色に関する測色的研究. 補緅誌 $16: 245-267$, 1972.

11）中川喜晴, 丸山剛郎, 下総高次. 陶材補経におけるシェイドセ レクション（色調選択）に関する研究 第 1 報 各種シェイド ガイドの構成分析について. 補緅誌 $16: 144-157,1972$.

12）日野年澄. ニューセラミックスのクラウン・ブリッジ臨床応用に 関する力学的研究. 阪大歯学誌 $35: 240-267,1990$.

13）納谷嘉信. 産業色彩学 97-106, 東京: 朝倉書店, 1980.

14）木村 博. 歯科理工学 138-148, 東京: クインテッセンス出版, 1988.

15) Skinner EW, Phillips RW (三浦維四). The Science of Dental Materials（スキンナー霜科材料学 219-233, 東京: 医歯薬出版, 1968) 1960.

16）丸山剛郎, 吉田皓, 陳 次忠ほか。陶材補緅における測色学 的研究. 補緅誌 $14: 109-119,1970$.

17) Seghi RR, Sorensen JA. Relative flexural strength of six new ceramic materials. Int J Prosthodont 8: 239-246, 1995. 